\title{
Review of Agriculture and Rural Development to Poverty Reduction in Cambodia: SWOT Analysis
}

\author{
Rathny Suy ${ }^{1}$--- Chakriya Choun ${ }^{2}$--- Leaksmy Chhay ${ }^{3}$ \\ ${ }^{1}$ School of Public Affairs, University of Science and Technology of China, Hefei, Anhui, 230026, China \\ Email:rathny@mail.ustc.edu.cn \\ ${ }^{2}$ School of Public Administration, Central South University, Changsha, Hunan, China \\ ${ }^{3}$ School of Management, University of Science and Technology of China, Hefei, Anhui, 230026, China
}

\begin{abstract}
Agriculture contributes immensely to the Cambodian economy in various ways; namely, in the provision of food for the increasing population; supply of adequate raw materials to a growing industrial sector; a major source of employment; generation of foreign exchange earnings; and, provision of a market for the products of the industrial sector among others. This study aims to review the background of agricultural and rural development in Cambodia to do action in poverty reduction in rural society. This study used a descriptive design to provide SWOT analysis based on secondary data such as kinds of literature, government reports, and NGOs documents.
\end{abstract}

Keywords: Agriculture, Rural development, Poverty reduction, SWOT, Cambodia.

Licensed: This work is licensed under a Creative Commons Attribution 4.0 License.

\section{Introduction}

Cambodia is situated in Southeast Asia and is also a low-income country in the region. Over two decades of war and conflict have left Cambodia becomes one of the poorest countries in the world, with extensive damage to its physical, social and human capital. The government has made significant efforts to rehabilitate the nation, with development partners taking an active part in development in various sectors (Farib, 2012).

In Cambodia, approximately $80 \%$ of the population is placed in rural areas, and $71 \%$ depend primarily on agriculture (largely rice) for their livelihoods (World Bank, 2006). Agriculture accounted for 32\% of GDP in 2008 and employed 57\% of the labour force in 2006 (Ngin, 2011; Ngo \& Chan, 2010). Although the current economy is still contributed to significantly by industry (at 22\% of GDP in 2008) and services (45\% of GDP in 2007 ), given that $30 \%$ of the populace are living in poverty (in 2007) and most of them are farmers in rural areas, an improvement in agriculture would seem the most effective approach in accelerating poverty reduction in Cambodia (NGOF, 2007; RGC, 2006; World Bank, 2006). Agriculture has also been identified as a key to diversifying the sources of economic growth, with the potential to reduce poverty, if focused on smallholders (CDRI-IDS, 2006). If growth in agricultural productivity can be enhanced by between $3 \%$ and 4 $\%$, the Cambodian Millennium Development Goal (MDG) on poverty targeted at 19.5\% in 2015 could be achieved.

Cambodia's economic performance over the past decade has been impressive, and poverty reduction in the country has made considerable progress. Over the past 10 years, economic growth has averaged 9.7\% per annum, while from 2004 to 2007, it averaged nearly 11.0\%. At the same time, poverty has been reduced significantly (around 10 percentage points in a decade) and is still fall, from $35.0 \%$ in 2004 to $30.1 \%$ in 2007 . Despite the main sources of growth being in non-agricultural sectors, agriculture still remains a large sector 
of the economy, comprising 32.5\% of gross domestic product (GDP) and absorbing 59.0\% of the total labour force (ADB, 2010). Exports have increased from almost zero to $65.0 \%$ of GDP in 2007, slightly falling to $52.7 \%$ in 2008 due to the impact of the global financial crisis (ADB, 2010).

However, there is concern that this growth has not benefited from a large proportion of the population and that sustaining this rapid growth and reducing poverty will prove difficult. The policies required to sustain growth are different from those to initiate it, and experience from other countries shows that very few have managed to achieve sustained growth over the longer term (Dani, 2007). While global economic history shows that the process of development usually entails a shift from agriculture to manufacturing and services, the consensus for Cambodia is that in the short to medium term, poverty reduction will require growth in rural areas, most likely through sustained agricultural growth and the ability to capture value added from agro processing (Dani, 2007).

Historically, agricultural diversification has been ineffective in Cambodia, but agro-industrialization and foreign investment appears to be increasing. Exports of raw agricultural products, such as cassava, maize, paddy, and soybeans to Thailand and Vietnam, are significant, although remain unrecorded. However, there are nascent signs of emerging rural enterprises in Cambodia concentrating on agroindustry, with the establishment of private rubber and cashew plantations, cassava starch factories for biofuel, and a rudimentary animal feed industry sponsored by CP Thailand. Further, over 2010-2011, reports of significant agribusiness investment pledges surfaced from Indonesia and Kuwait to develop Cambodia's rice industry (i.e., close to $\$ 1$ billion in planned investments in irrigation, contract farming, and modern rice mills), and there are also indications that private equity firms are standing by to invest over $\$ 600$ million in agribusiness.

In recent years have made the country somewhat less aid dependent, and increasing levels of domestic savings have further deepened the country's ability to sustain its own growth. For instance, savings have gone from $2.3 \%$ of GDP in 1998 to $30.3 \%$ in 2008 (ADB, 2010). Despite these generally positive signs, however, there is justifiable concern about Cambodia's ability to seize the opportunities presented. A set of structural and institutional constraints to agricultural and rural development exists, which, unless addressed by appropriate interventions and policies will result in a slowing of economic growth and poverty reduction (ADB, 2012). This review paper aims to study on agricultural and rural development in Cambodia, and how to reduce poverty in rural areas. This study also provides SWOT analysis based on secondary data.

\section{Literature Review}

\subsection{The Concept of Agriculture and Rural Development}

Concept of agriculture and rural development has been conceived as a response to the increasing external pressure on rural communities. Therefore, it is necessary to redefine identities, strategies, practices, and networks within the territory to overcome the current model of the organization by single commodity chains and sectors and redefine the territory as a competitive production unit based on economies of scope. Agricultural development, a subset of economic development, implies a sustained increase in the level of production and productivity over a reasonable length of time and the subsequently improved wellbeing of farmers as reflected in their higher per capita income and standard of living.

MacRae, Hill, Henning, \& Bentley (1990) defined that the sustainable agriculture is at the same time a philosophy and a system of farming. It is rooted in a set of values that reflect an awareness of both ecological and social realities and a commitment to responding appropriately to that awareness. It emphasizes design and management procedures that work with natural processes to conserve all resources and minimize waste and environmental damage, while maintaining and improving farm profitability (MacRae, Hill, Henning, \& Bentley, 1990).

The meaning of rural development has been the subject of much debate and little agreement. The definition of rural development has evolved through time as a result of changes in the perceived mechanisms or goals of development. The rural development as a process whereby concerted efforts are made in order to facilitate the significant increase in rural resources productivity with the central objective of enhancing rural income and creating employment opportunity in rural communities for rural dwellers to remain in the area (Olayide, 1981). According to Ploeg et al., (2000) explained that rural development is reconstructing the eroded economic base of both the rural economy and the farm enterprise, and represents the well-understood self-interest of increasing sections of the rural population (Ploeg et al., 2000).

Rural development can be distinguished from Agricultural Development which it entails and transcends. Efforts by such governments to pump money into agricultural development did not yield the meaningful change desired hence, efforts should be made to include provision of modern infrastructure, primary health care, food and shelter, employment opportunities, recreational facilities, affordable and compulsory primary and secondary education, loans and other incentives, to be part of rural development for the benefits of rural dwellers (Olayiwola \& Adeleye, 2005). From the foregoing, it is obvious that rural development is not a oneoff thing or an immediate and snap phenomenon. 


\subsection{Agriculture and Rural Development in Cambodia: An Overview}

Cambodia has great potential for agricultural development. In this regard, and faced by a number of extremely difficult challenges, government and development partners have made great efforts in relation to formulating and implementing policy and programming to accelerate development in the sector. This section presents an overview of the progress in agricultural development, the evolution of ARD policy, and the institutional arrangements for coordinating the task in the sector.

Cambodia is a post-conflict country, and still emerging from two decades of war and civil strife (1970s and 1980 s) and a decade of internal conflict and unstable politics (1990s). First, the country transformed from a centrally planned to an open market economy in 1989, which resulted in major changes, such as the official recognition of private land ownership and the liberalization of trade, industry and transportation. Second, free market economy policy was officially adopted in 1993, simultaneous to the establishment of the Royal Government of Cambodia's first mandate.

The Cambodian economy has rapidly developed, with an average growth rate of over $9 \%$ in the last decade (see Figure 1). The highest growth rate of $13.3 \%$ was in 2005 and was thanks to strong growth in garments, tourism and construction, and agriculture due to the blessing weather in the year (Hang, 2010). In 2007, the economy continued to rise at $10.2 \%$ even during the critical period of the global economy. Notwithstanding, the GDP growth was contracted to $6.7 \%$ in 2008 due to the inflationary pressure from high oil and commodity prices (IMF, 2009; Tong \& Hem, 2010) and to $0.1 \%$ in 2009 because of impacts from the world economic crisis. Cambodia is gradually recovering from the global economic crisis and the growth rate in 2010 was forecast at $5.5 \%$.

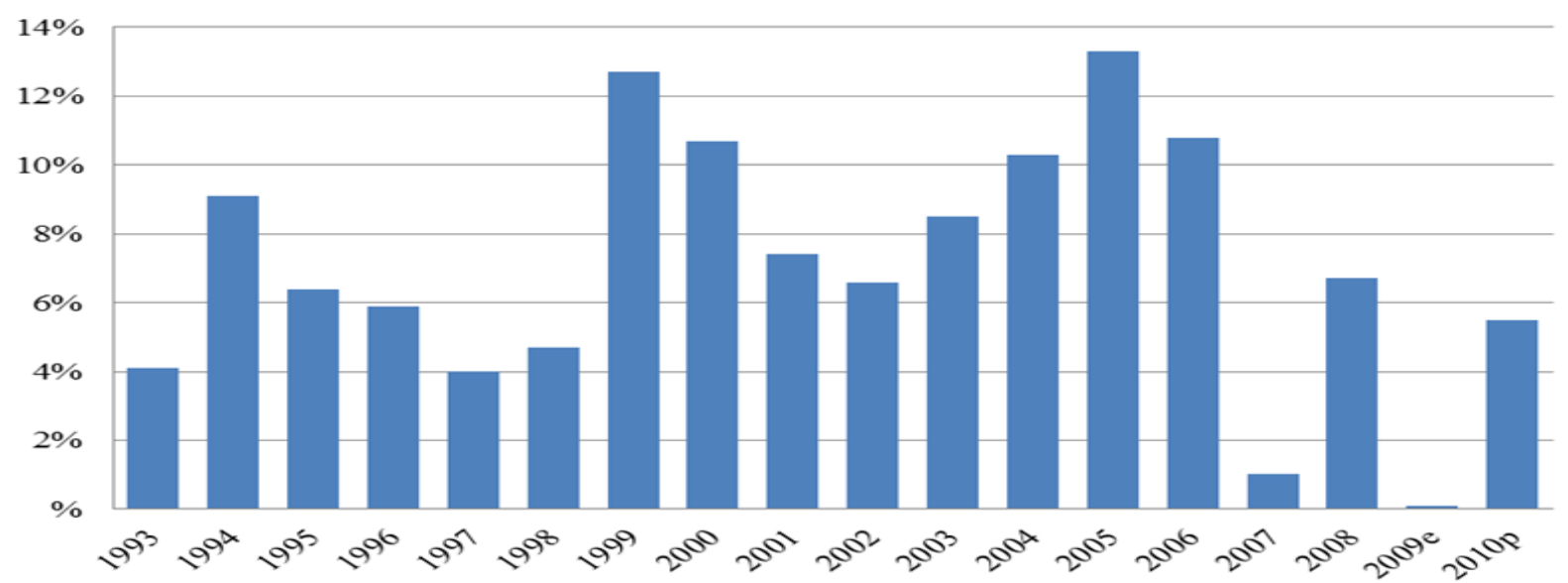

Source: Hang (2010); Ngin (2011)

Figure-1. GDP Growth, 1994-2010

The recovery is chiefly owing to the re-emerging growth in industry (at 5.7\% in 2010) and services (at $2.4 \%$ in 2010) sectors, while agriculture grew at $2.3 \%$ in 2010, a downturn from $5.7 \%$ and $5.6 \%$ in 2008 and 2009 respectively (see Table 1). Growth in garment exports (over $21 \%$ in the first nine months of 2010 and estimated $15 \%$ in 2011) significantly attributes to the spur in the industrial sector (Hang, 2010). This pattern of economic growth highlights the central proportions of industry and services sectors in the GDP increase in relation to agriculture sector's in the last decade (see Figure 2).

Table-1. Macroeconomic Indicators: 2008-2010

\begin{tabular}{|c|c|c|c|}
\hline & 2008 & 2009 & 2010 \\
\hline GDP (nominal, \$ million) & 10,337 & 10,391 & 11,304 \\
\hline GDP (per capita, in $\$$ ) & 738 & 731 & 783 \\
\hline Agriculture & $5.7 \%$ & $5.6 \%$ & $2.3 \%$ \\
\hline Industry & $4.0 \%$ & $-2.5 \%$ & $5.7 \%$ \\
\hline Budget expenditure (\% GDP) & $15.9 \%$ & $20.4 \%$ & $18.4 \%$ \\
\hline Overall deficit (\% GDP) & $-2.9 \%$ & $-6.4 \%$ & $-5.9 \%$ \\
\hline Inflation (average) & $19.7 \%$ & $-0.6 \%$ & $4 \%$ \\
\hline Gross Foreign Reserves ( $\$$ million) & 2,164 & 2,367 & 2,500 \\
\hline
\end{tabular}




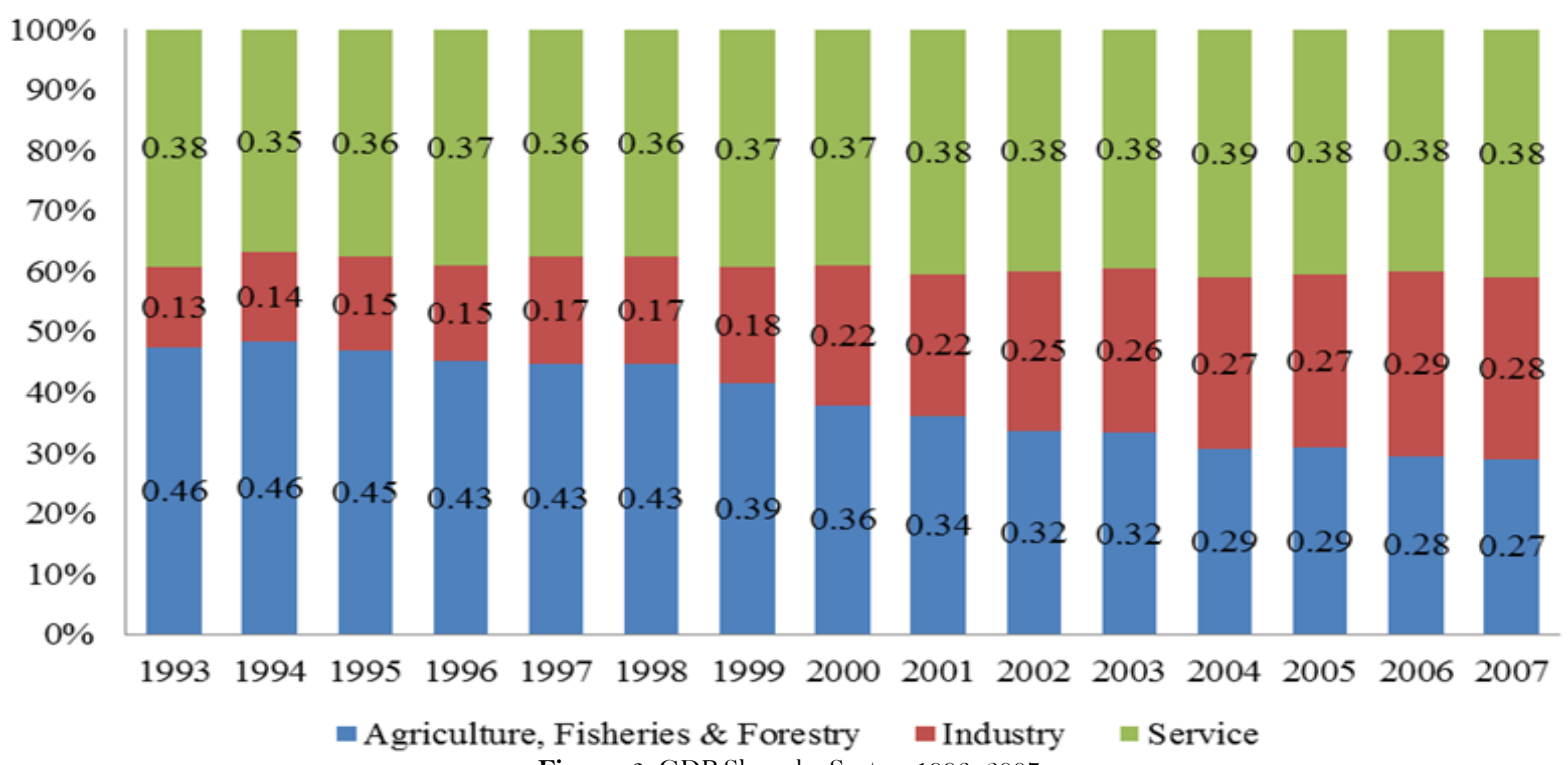

Source: NIS (2008); Tong \& Hem (2010)

Figure-2. GDP Share by Sector, 1993-2007

The economic growth needs to be reflected in the employment of the labour force. As reported in Table 2 , Cambodia is predominantly agrarian. In $1995,81 \%$ of the labour force was involved in agriculture. Nonetheless, the percentage of employment in agriculture shrank to $57 \%$ in 2006 due to the mushrooming of garments industry since the early 1990s. Conversely, manufacturing and construction employed merely $3 \%$ of the labour force in 1995, but it rose to $14 \%$ in 2006 (Ngin, 2011). Likewise, the services sector has absorbed more labour force, surging from $16 \%$ in 1995 to $28 \%$ in 2006 . This trend of labour force signifies that despite the dominance of agriculture its contribution to GDP is increasingly minimal; down from $46 \%$ in 1993 to $27 \%$ in 2007 (see Figure 2).

Table-2. Cambodian Employments by Sector, 1995-2006 (percentage)

\begin{tabular}{lllllllllllll}
\hline Year & $\mathbf{1 9 9 5}$ & $\mathbf{1 9 9 6}$ & $\mathbf{1 9 9 7}$ & $\mathbf{1 9 9 8}$ & $\mathbf{1 9 9 9}$ & $\mathbf{2 0 0 0}$ & $\mathbf{2 0 0 1}$ & $\mathbf{2 0 0 2}$ & $\mathbf{2 0 0 3}$ & $\mathbf{2 0 0 4}$ & $\mathbf{2 0 0 5}$ & $\mathbf{2 0 0 6}$ \\
\hline Agriculture & 81 & 78 & 79 & 77 & 76 & 74 & 70 & 67 & 64 & 60 & 59 & 57 \\
Industry & 3 & 5 & 5 & 9 & 6 & 8 & 10 & 11 & 12 & 13 & 13 & 14 \\
Service & 16 & 17 & 16 & 14 & 17 & 18 & 20 & 21 & 24 & 27 & 27 & 28 \\
\hline Source: IMF (2009); Tong \& Hem (2010)
\end{tabular}

\section{Method}

This study used a descriptive design, by exploring some of the secondary data such as literature review, government report, and NGOs report that discusses about evaluate the SWOT analysis of agriculture and rural development in Cambodia.

\section{Discussion}

Agricultural development, a subset of economic development, implies a sustained increase in the level of production and productivity over a reasonable length of time and the subsequently improved wellbeing of farmers as reflected in their higher per capita income and standard of living. Sustainable national development through agricultural and rural development is generally concerned with the need for agricultural and rural development practices to be economically viable, their adaptability and flexibility over time to respond to the demands for food and fibre (both high and low). Because agriculture is affected by changes in market and resource decision in other sectors and regions, it is important that these changes do not provide a rationale for depleting the agricultural and rural resource base locally (Oni, 2008). This section discusses about SWOT of agriculture and rural development in Cambodia based on secondary data, so in figure 3 showed about SWOT analysis was used to evaluate the Strengths, Weaknesses, Opportunities, and Threats involved in any venture. 


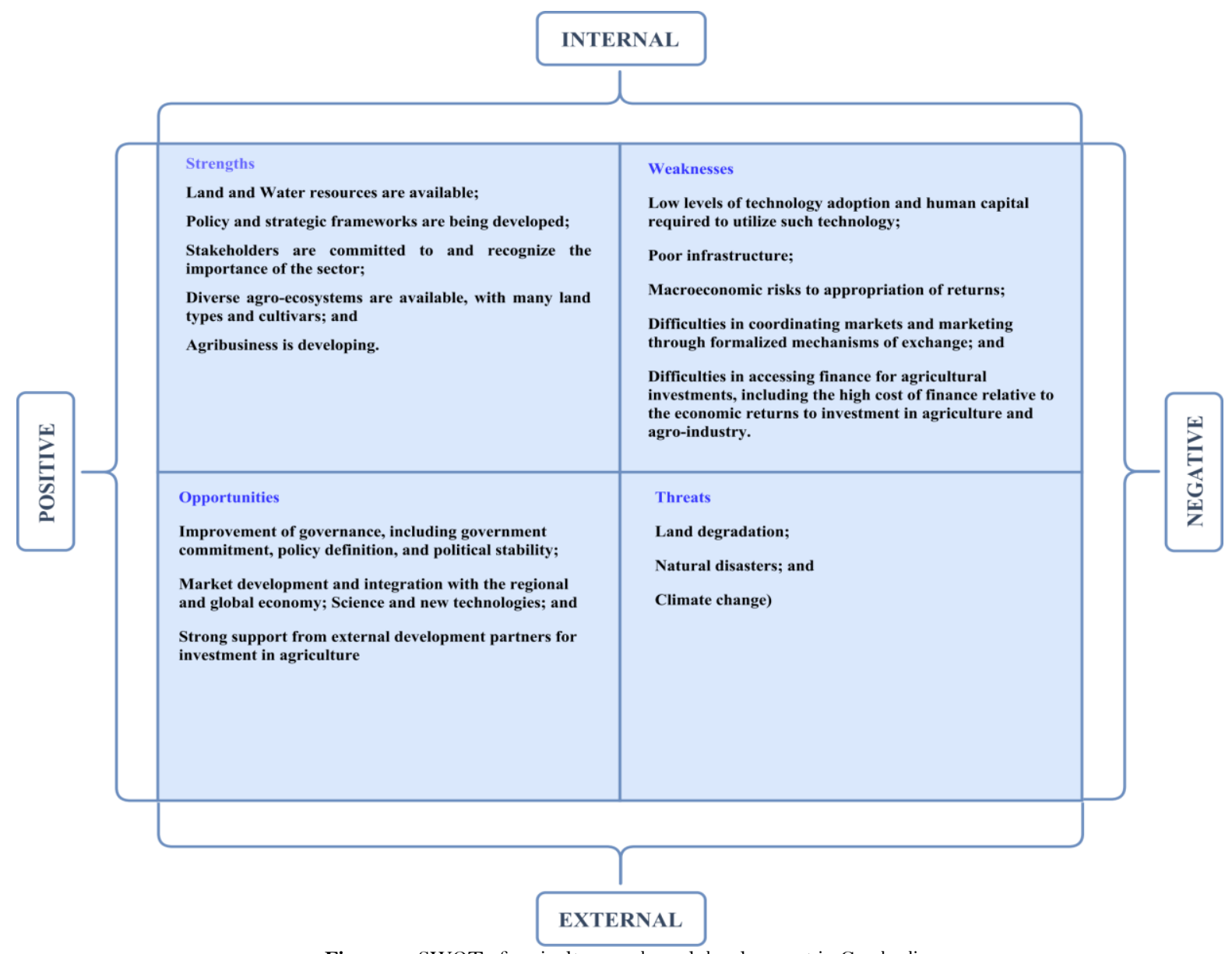

Figure-3. SWOT of agriculture and rural development in Cambodia

Note: This figure was created by authors based on secondary data

\subsection{Strengths}

Agriculture sector is still contributing $37 \%$ to the GDP and employed about $67 \%$ of the workforce. The country has achieved agricultural production increased by $4.3 \%$ with a paddy harvest at record levels (about 9.3 million tons). The country's agricultural resources consist primarily of 3.7 million hectares of cultivated land, of which $75 \%$ is devoted to rice (FAPDA, 2014).

In 2013, Cambodia exported a record level of 1.2 million tons of rice, accounting for more than $3 \%$ of the worldwide total rice exports. Cambodia's economic performance over the past decade has been admirable, economic growth has averaged 9.7\% per annum, while from 2004 to 2007, it averaged nearly $11.0 \%$ (ADB, 2012). The fallout of the global financial crisis pushed GDP growth to almost zero in 2009 for the first time, but forecasts are for a return to higher positive growth in 2010-2011. At the same time, poverty has fallen (around 10 percentage points in a decade), going from $35.0 \%$ in 2004 to $30.1 \%$ in 2007 . As a result of such economic development, income per capita increased from $\$ 250$ in 1998 to $\$ 795$ in 2008 (ADB, 2012).

Cambodia has just re-entered the world market as a rice exporting nation, following a 30-year hiatus caused by war, political isolation, and a decimated agricultural sector. Given the country's recent success in achieving surplus rice production, the Cambodian government is bent on expanding its production and export capacity and becoming a major rice export nation (USDA, 2010). Public statements by government ministers in the last year indicate that Cambodia wants to double rough rice production by 2015 to approximately 15.0 million tons (9.45 million milled basis) and export 8.0 million (5.0 million tons milled rice) (USDA, 2013). Analysts from the USDA Foreign Agricultural Service (FAS), the Economic Research Service, and the U.S. Embassy in Phnom Penh investigated rice production prospects in Cambodia and the outlook for continued growth in the sector during recent travel in the country.

It is generally believed that rice has been continuously cultivated in Asia for over 10,000 years, having been first domesticated in eastern India and the lowland plains of Southeast Asia. In Cambodia today, rice is the overwhelmingly predominant food crop, is grown on an estimated 2.3 million hectares or nearly $85 \%$ of the country's total cultivated area. The lowland plain itself surrounds a very large wetland area, and includes Cambodia’s largest inland water body, Tonle Sap Lake or “Great Lake” (USDA, 2010).

The Cambodian government recognizes that its goal of joining the ranks of the world's major rice export nations will require the considerable additional development of its irrigation infrastructure in the heavily populated south eastern Mekong River floodplain and in the lowlands surrounding Tonle Sap, Cambodia's 
"great lake". The Ministry of Water Resources and Meteorology (MOWRAM) has reported that they successfully brought approximately 650,000 hectares of rice area under irrigation between 1996 and 2007, and have plans and finance sufficient to irrigate an additional 800,000 hectares over the next decade. In total, MOWRAM acknowledged that it had received commitments totalling the US $\$ 1.1$ billion for irrigation infrastructure development, with the additional US $\$ 850$ million pledged in October 2009 from the Chinese government for the construction of dams (hydro), irrigation, roads, and port upgrades (USDA, 2010).

\subsection{Weaknesses}

In this section, the weaknesses have five main areas based on the framework of Hausmann, Rodrik, and Velasco (2005) to set of critical and binding constraints to poverty reduction, improved productivity in the rural sector, and improved private and public engagement in increasing value added (see Figure 4). Basically, these critical constraints include: 1) low levels of technology adoption and human capital required to utilize such technology; 2) poor infrastructure (e.g., rural roads; irrigation; and post-harvest storage and handling, processing, transport, and logistics); 3) microeconomic risks to appropriation of returns (e.g., property rights, corruption, and the business-enabling environment related to taxation and fees); 4) difficulties in coordinating markets and marketing through formalized mechanisms of exchange; and 5) difficulties in accessing finance for agricultural investments, including the high cost of finance relative to the economic returns to investment in agriculture and agro-industry.

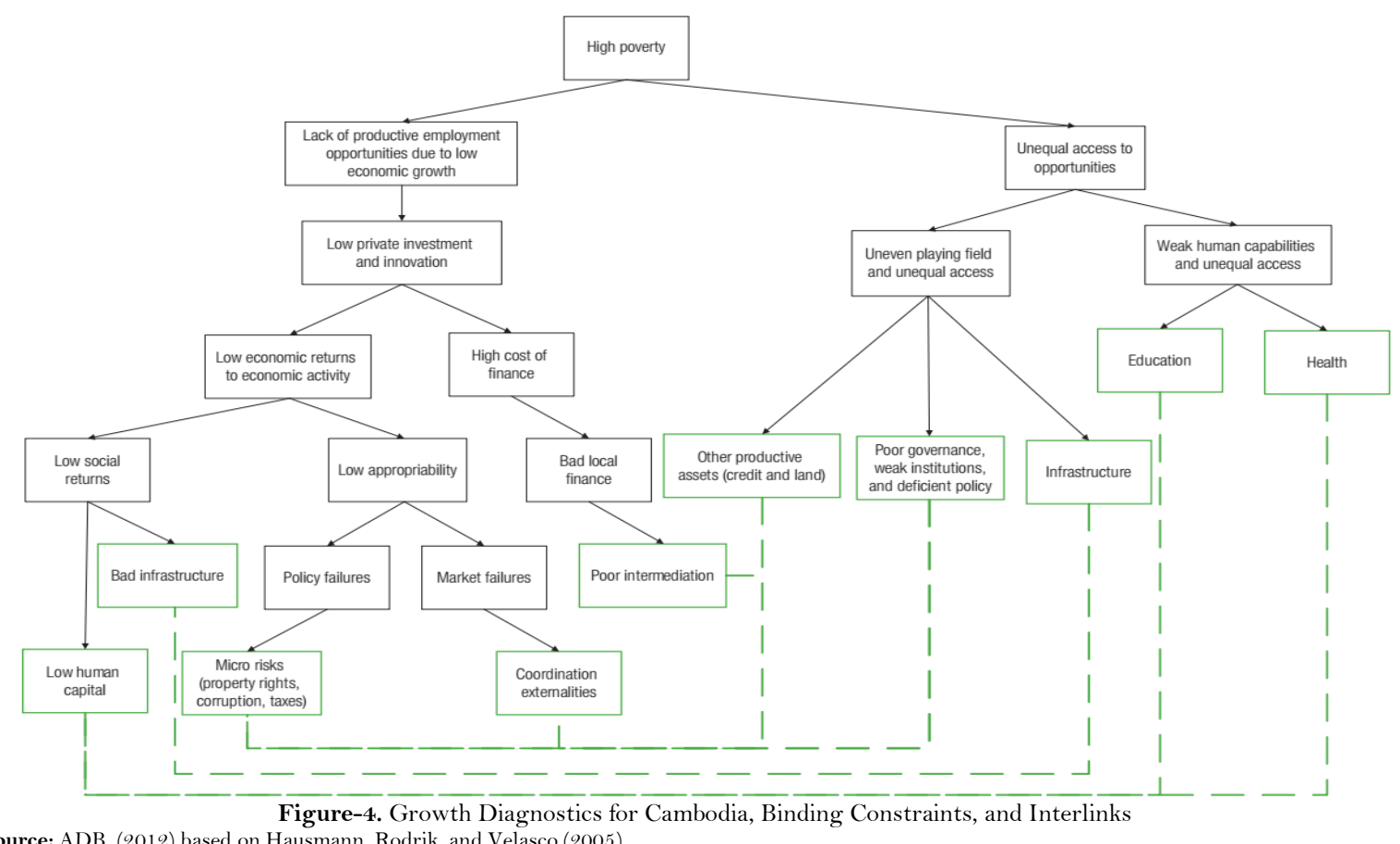

Source: ADB. (2012) based on Hausmann, Rodrik, and Velasco (2005)

Many of these critical constraints are related. Unequal access to opportunities manifests itself in fewer educational opportunities for the poor and reduced health outcomes, which in turn are related to human capital constraints. The uneven playing field for the poor relative to the rich manifests in unequal access to infrastructure, productive assets such as land and credit, and policy outcomes that discriminate against the poor.

The potential for agriculture as a driver for rural economic growth lies not so much in specific products or processes but in overall increases in efficiency arising from the removal of subsector-wide constraints. While it is important to address these constraints, this review points out that once land tenure, human capital, infrastructure, market access, and access to credit have been achieved, movement of smallholder farmers along the commercialization path to improved household incomes will occur only after the enabling environment of value chains have been addressed (ADB, 2012). However, it is clear that there are a few specific areas in which considerable benefits could be realized.

Actions are needed to promote the use of modern technology in production and post-harvest storage processes; expand investment in agricultural research and development; strengthen rural infrastructure, particularly roads and irrigation drainage systems; develop markets and institutions; improve financially intermediation; and improve access to health and education services (ADB, 2012). 


\subsection{Threats}

Land Degradation: According to the UNCCD and WOCAT, takes many forms. The main forms in Cambodia are soil degradation, and deforestation, and consequent loss of biodiversity. The FAO study, Cambodia had the second lowest level of degradation (at 43\%). However, this still involved about 7.7 million ha of land areas (FAO, 2014, 2016).

Environmental Conditions and Disasters: Cambodia experienced extensive rainfall during the early wet season of 2013, which enabled timely planting of the wet season rice crop. However, heavy rain in September upstream of the Mekong Basin and in Cambodia caused flash floods and river flooding; affecting 20 provinces (see Figure 5). Flooding has caused 168 death, affected 377,354 households and 139,000 hectares of wet season rice cultivated areas (of which 5,700 hectares were destroyed), as well as other infrastructures (Baran, Schwartz, \& Kura, 2009; Kim \& Chem, 2014).

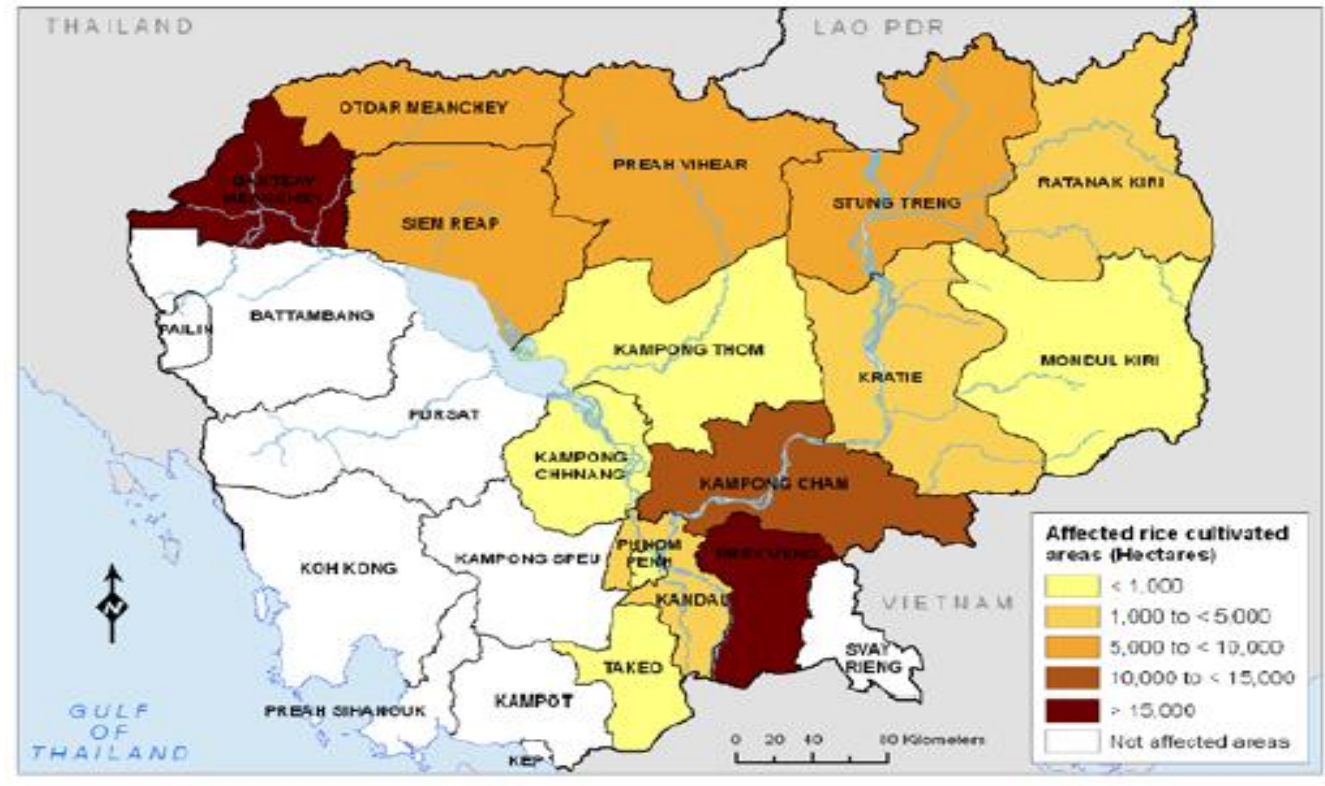

Figure-5. Rice cultivated areas affected by floods Source: Ministry of Agriculture, Forestry and Fisheries, Cambodia

Climate Change: Climate change is also another important threat hanging like a domicile`s word over Cambodian agriculture. The average temperature in Cambodia has been increasing since 1960 by $0.8^{\circ} \mathrm{C}$, and with it, the frequency of unusually hot days and nights has increased as well. Further $0.3-0.6^{\circ} \mathrm{C}$ increases are expected by 2025. Alternative estimates put the expected warming at $0.7-2.7^{\circ} \mathrm{C}$ of the 2060 s. Temperature increases will be more severe from December to June. All climate change models agree that rainfall in Cambodia will increase, but the magnitude of change is uncertain (Baran et al., 2009; Kim \& Chem, 2014).

\subsection{Opportunities}

Rising global and regional demand for food will continue to provide markets for increased Cambodian exports, which will be facilitated by the continuation of market-oriented agricultural and trade policies (FAO, 2014). Public investments will help continue to reduce the costs of doing business and attract private investments to create jobs.

Some drivers underpinning future agricultural growth in Cambodia will be identical to those of the past. For example, GDP growth will increase domestic demand for more diverse food and encourage further outmigration of labor from agriculture (Kem, Chhim, Theng, \& So, 2011). Depending on the World Bank (2013), Cambodia's GDP will continue to expand rapidly up to 2030, though at a slower pace (slightly over $7 \%$ ) than over 2000-2010 (8.2\%). GDP is expected to grow in real terms from its present value of $\$ 13$ billion to $\$ 23$ billion by 2020 , and to nearly quadruple to $\$ 50$ billion by 2030 population growth expected to decline from $1.4 \%$ to $1.1 \%$ over this projection period, real GDP per capita would increase from $\$ 957$ in 2012 to $\$ 2,733$ by 2030 (Kean, 2012).

Rising ASEAN and global demand for food will offer market outlets for Cambodian exporters, but penetrating foreign markets will be more challenging. The further increase in cross-border trade will require Cambodia to have an adequate capacity and network of agreements in place with major trading partners (especially China) for food safety and quality standards, double tax agreements, transit, and harmonized trade and commerce legislation (e.g., anti-dumping, labelling, trademark protection). Adequate physical and institutional infrastructure is needed to achieve such competitiveness, including more stable and cheaper 
access to energy, improved transportation network and logistics systems, highly effective information and communication systems, and financial institutions to support trade and investment (Hang, 2010).

National Strategic Development Plan, it is the Royal Government's overall goal that is "poverty reduction and economic growth through enhancement of agriculture sector development”. This strategic plan always update the goal every five years to ensure food security, increase incomes, create employment and improve nutrition status for all people in local and global by productivity and diversification, and commercialization of agriculture with environmentally sound protection and food security (Kem et al., 2011).

\section{Concluding Remarks}

The Cambodian government has over the years formulated good agricultural but such policies have been found inefficient and ineffective since the intended results were not realized because the weaknesses of ARD have much than strengths. To reach the Millennium Goals of cutting hunger and poverty, agricultural growth must be handed over on top of the development agenda. In the future, the weaknesses and threats will be abolished. The best way that in order to facilitate rural development, the government should adopt an integrated rural development approach this is a multidimensional strategy for enhancing the quality of life of rural people. It is based on the assumption that the socio-economic fragment of the traditional rural system is obsolete, so integrated rural development strategies should be designed to change this framework and promote structural changes. The rural people should be deeply involved. There is needed for training and retraining of the rural people to enhance the dissemination of new skills and ideas on the establishment, management and skills of small-scale industries.

\section{Acknowledgments}

The authors would like to thank the anonymous reviewers and the academic editor of this journal for the invaluable comments and suggestions which have substantially improved the manuscript.

\section{References}

ADB. (2010). Agriculture and Rural Development Sector in Cambodia. Metro Manila, Philippines: Asian Development Bank. pp: 2 .

ADB. (2012). Rural Development for Cambodia: Key Issues and Constraints. Metro Manila, Philippines Asian Development Bank. pp: 127.

Baran, E., Schwartz, N., \& Kura, Y. (2009). Climate change and fisheries: vulnerability and adaptation in Cambodia Reducing poverty and hunger by improving fisheries and aquaculture. Penang, Malaysia: The WorldFish Center. pp: 8.

CDRI-IDS. (2006). Roundtable Discussion on Cambodian Development Issues. Phnom Penh: Cambodia Development Resource Institute and Institute of Development Studies.

Dani, R. (2007). One Economics, Many Recipes: Globalization, Institutions, and Economic Growth New Jersey: Princeton University Press.

FAO. (2014). Food and agriculture policy trends Country fact sheet. Phnom Penh, Cambodia: Food and Agriculture Organization

FAO. (2016). Cambodia: Economy, Agriculture and Food Security. Phnom Penh, Cambodia: Food and Agriculture Organization.

FAPDA. (2014). Socio-economic context and role of agriculture Country fact sheet on food and agriculture policy trends. Phnom Penh, Cambodia: Food and Agriculture Policy Decision Analysis. pp: 6.

Farib, S. (2012). Cambodia Report: News and Views on Cambodia. from http://www.apri.ac.nz/camnews_jun02.html

Hang, C. N. (2010). The Cambodian Economy and Development: Review and Analysis: Presentation at the Annual General Meeting of the Cambodian Economic Association.

IMF. (2009). Cambodia: Statistical Appendix. . Washington, D.C.: International Monetary Fund.

Kean, S. (2012). The Rice Situation in Cambodia. Phnom Penh, Cambodia: Department of Horticulture and Subsidiary Crops under the General Directorate of Agriculture, Ministry of Agriculture, Forestry, and Fisheries. pp: 41

Kem, S., Chhim, C., Theng, V., \& So, S. (2011). Policy Options for Vulnerable Groups: Income Growth and Social Protection. Phnom Penh, Cambodia: Cambodia's leading independent development policy research institute $(\mathrm{CDRI})$. pp: 80.

Kim, S., \& Chem, P. (2014). Climate Change Vulnerability and Adaption Assessment Methods and Tools Applied in Cambodia. Phnom Penh, Cambodia: Cambodia’s Leading Independent Development Policy Research Institute (CDRI). pp: 6.

MacRae, R. J., Hill, S. B., Henning, J. C., \& Bentley, A. J. (1990). Policies, programs, and regulations to support the transition to sustainable agriculture in Canada. American Journal of Alternative Agriculture, 5(2): 76-92. doi: 10.1017/S0889189300003325

Ngin, C. (2011). Economic Growth, Agriculture and Poverty Reduction in Cambodia. Paper presented at the Third Annual Conference of the Academic Network for Development in Asia (ANDA): The 
International Seminar on Skills Development for the Emerging New Dynamism in Asian Developing Countries under Globalization, The Graduate School of International Development, Nagoya University, Japan.

Ngo, S., \& Chan, S. (2010). Does Large-Scale Agricultural Investment Benefit the Poor?. Phnom Penh: Cambodian Economic Association. pp: 55.

NGOF. (2007). NGO Position Papers on Cambodia's Development in 2006. Phnom Penh: NGO Forum on Cambodia.

Olayide, S. O. (1981). Elements of rural economics. [Ibadan]: Ibadan University Press Pub. House.

Olayiwola, L. M., \& Adeleye, O. A. (2005). Rural development and agro-industrial promotion in Nigeria: concepts strategies and challenges. Journal of Social Sciences, 11(1), 57-61 doi: DOI 10.1080/09718923.2005.11892499

Oni, K. C. (2008). Agro-Industrialization for National Food Security: Issues, Constraints and Strategies. Paper presented at the the 32nd Annual Conference and General Meeting of NIFST, LAUTECH.

Ploeg, J. D. V. D., Renting, H., Brunori, G., Knickel, K., Mannion, J., Marsden, T., . . Ventura, F. (2000). Rural development: from practices and policies towards theory. Sociologia Ruralis, 40(4): 391-408.

RGC. (2006). National Strategic Development Plan 2006-2010. Phnom Penh: Royal Government of Cambodia. pp: 60.

Tong, K., \& Hem, S. (2010). Chinese Investment in Cambodia. In Annual Development Review 2009-10. Phnom Penh: Cambodia Development Resource Institute.

USDA. (2010). Cambodia: Future Growth Rate of Rice Production Uncertain A Commodity Intelligence Report: United States Department of Agriculture. pp: 10.

USDA. (2013). Cambodia: Seasonal Flooding Impacts Wet Season Rice Production in 2013 A Commodity Intelligence Report: United States Department of Agriculture. pp: 3.

World Bank. (2006). Cambodia: Halving Poverty by 2015?. Phnom Penh: The World Bank Office, Cambodia, 4: 4 . 